\title{
Analisa Faktor Dominan Mahasiswa Kesulitan Memahami Bahasa Pemrograman Menggunakan Metode C4.5
}

\author{
P.P.P.A.N.W Fikrul Ilmi R.H Zer ${ }^{1}$,Dedy Hartama², Sundari Retno Andani ${ }^{3}$ \\ 1,2STIKOM Tunas Bangsa Pematangsiantar \\ ${ }^{3}$ AMIK Tunas Bangsa Pematansiantar \\ 1,2,3Jl. Jendral Sudirman Blok A No. 1, 2 dan 3, Pematangsiantar, 0622-22431 \\ 1fikrulilmizer@gmail.com, ${ }^{2}$ dedyhartama@amiktunasbangsa.ac.id, \\ ${ }^{3}$ sundari.ra@amiktunasbangsa.ac.id
}

\begin{abstract}
Students' understanding of teaching and learning is determined by academic performance and lecturers who give teachings to students. Among them is the education of programming languages. Programming language is one of the main subjects at AMIK Tunas Bangsa Pematangsiantar. Many students buy programs in the final project so that students have difficulty answering questions from examiners $n$ during the trial. The statement of students in difficulty understanding different programming languages. The factors used in the study are lecturer factors, programming language factors, facility factors, lab assistant factors and interest factors. The purpose of this study is to provide academic decision makers in taking solutions to overcome this. The method used in this study is Classification using the C4.5 method as many as 90 data. The results of the study have an accuracy of $84.44 \%$ with a Factor Interest is the highest factor in the analysis and Lecturer Factors as the highest factor of students who do not understand the category of Good and Less. It can be concluded that academics provide good education and provide motivation for dynamic programming languages to keep up with the times, especially in the industrial world. With the results of this study, it contributed greatly to AMIK Tunas Bangsa in making decisions to minimize students buying programs. Academic success in educating students is by giving students an acceptable degree in the industry in accordance with the education and teaching provided.
\end{abstract}

Keywords: Students, Understanding, Programming Language, C4.5

Abstrak - Pemahaman mahasiswa dalam belajar mengajar ditentukan dari kinerja akademik dan dosen yang memberikan ajaran kepada mahasiswa/i. Diantaranya adalah pendidikan bahasa pemrograman. Bahasa pemrograman merupakan satu diantara matakuliah utama di AMIK Tunas Bangsa Pematangsiantar. Banyak mahasiswa/i yang membeli program dalam proses pengerjaan Tugas Akhir sehingga mahasiswa kesulitan menjawab pertanyaan dari penguji saat sidang. Pernyataan mahasiswa/i dalam kesulitan memahami bahasa pemrograman berbeda-beda. Faktor yang digunakan dalam penelitian adalah faktor dosen, faktor bahasa pemrograman, faktor fasilitas, faktor asisten lab dan faktor minat. Tujuan penelitian ini untuk memberikan pengambil keputusan pihak akademik dalam mengambil solusi untuk mengatasi tersebut. Metode yang digunakan dalam penelitian ini adalah Klasifikasi dengan menggunakan metode C4.5 sebanyak 90 data. Hasil penelitian terdapat akurasi sebesar 84,44 \% dengan Faktor Minat adalah faktor tertinggi dalam analisa dan Faktor Dosen sebagai faktor tertinggi mahasiswa yang tidak paham dengan kategori Baik dan Kurang. Dapat disimpulkan pihak akademik memberikan pendidikan yang baik dan memberikan motivasi bahasa pemrograman dinamis mengikuti perkembangan zaman terutama dunia industri. Dengan hasil penelitian ini memberikan kontribusi yang besar kepada AMIK Tunas Bangsa dalam mengambil keputusan untuk menimalisir mahasiswa membeli program. Kesuksesan akademik dalam mendidik 
mahasiswa/i adalah dengan memberikan mahasiswa/i dapat diterima di dunia industri sesuai dengan pendidikan dan pengajaran yang diberikan.

Kata kunci: Mahasiswa, Pemahaman, Bahasa Pemrograman, C4.5

\section{PENDAHULUAN}

Data Mining didasarkan pada jumlah data yang tersimpan dalam basis data semakin besar[1]. Data Mining termasuk dalam proses KDD (Knowledge Discovery Database) yang merupakan proses yang dibantu oleh komputer untuk menggali dan menganalisis sejumlah besar himpunan data dan mengekstrak informasi dan pengetahuan. Data Mining terdiri dari beberapa fase yaitu Estimasi, Klustering, Prediksi, Klasifikasi dan Asosiasi. Data Mining Klasifikasi memiliki salah satu metode yaitu Decision Tree. Decision Tree dengan algoritma C4.5 merupakan salah satu metode klasifikasi yang menggunakan representasi struktur pohon (Tree) dimana setiap node mempresentasikan atribut, cabangnya mempresentasikan nilai dari atribut, dan daun mempresentasikan kelas[2]. Algoritma C4.5 diperkenalkan oleh Quinlan (1996) sebagai versi perbaikan dari ID3 (Interactive Dichotomiser 3) dan dapat digunakan untuk mencari faktor dominan untuk mencari suatu keputusan, salah satunya menentukan faktor dominan kesulitan bahasa pemrograman. Bahasa Pemrograman merupakan notasi yang digunakan untuk menulis program di komputer. Bahasa Pemrograman adalah salah satu matakuliah penting di Perguruan Tinggi berbasis komputer. AMIK Tunas Bangsa Pematangsiantar adalah salah satu Perguruan Tinggi yang menghasilkan bibit-bibit pekerja yang terjun kedunia kerja terutama dalam hal pemrograman. AMIK Tunas Bangsa terdiri dari dua program studi yaitu Manajemen Informatika dan Komputerisasi Akuntansi. Matakuliah bahasa pemrograman diajarkan secara teori dan praktik. Praktik pemrograman diberikan bahan ajar berupa modul yang berisi kode-kode program dan algoritma yang diajarkan. Penulisan Tugas Akhir untuk Manajemen Informatika dan Komputerisasi Akuntansi diharuskan menggunakan bahasa pemrograman sebagai solusi yang digunakan untuk implementasi penyelesaian suatu masalah. Sistem yang dibangun adalah Sistem Informasi, cara kerja dari sistem yang dibangun adalah menyimpan data, mengubah data, menghapus data, dan menampilkan laporan yang baik dan tepat. Terdapat faktor mahasiswa yang kesulitan memahami bahasa pemrograman seperti pemahaman algoritma yang digunakan, logika dalam pemrograman, dan kesalahan penulisan kode program. Dari faktor tersebut mahasiswa sulit mengerjakan Tugas Akhir dikarenakan belum memahami bahasa pemrograman. Pemahaman yang belum kuat menimbulkan mahasiswa kesulitan menjawab pertanyaan yang diberikan dosen penguji dan mahasiswa AMIK Tunas Bangsa diharuskan memahami bahasa pemrograman agar dapat mengikuti perkembangan zaman dan dunia industri di masa mendatang.

Permasalahan yang tertera diatas, penulis melakukan analisa dalam mencari faktor dominan mahasiswa kesulitan memahami Bahasa Pemrograman dengan menggunakan Data Mining metode C4.5. Data yang digunakan dengan memberikan kuesioner kepada mahasiswa angkatan 2016 dan angkatan 2017 di AMIK Tunas Bangsa. Parameter yang digunakan dalam penelitian ini adalah Faktor Dosen, 
Faktor Bahasa Program, Faktor Fasilitas, Faktor Asisten Lab dan Faktor Minat. Dalam menganalisa faktor dominan mahasiswa kesulitan memahami bahasa pemrograman, penelitian ini dilandasi oleh penelitian sebelumnya oleh[3] pada studi kasus : Penerapan Algoritma C4.5 untuk Klasifikasi Predikat Kelulusan Mahasiswa Fakultas Komunikasi dan Informatika Universitas Muhammadiyah Surakarta dengan kesimpulan Algoritma C4.5 dapat disimpulkan variabel yang paling tinggi pengaruhnya terhadap predikat kelulusan adalah partisipasi mahasiswa menjadi asisten. Probabilitas predikat "Cumlaude" terdapat kelompok mahasiswa yang pernah menjadi asisten lebih tinggi dibandingkan dengan yang tidak menjadi asisten dan penelitian sebelumnya oleh[4] pada studi kasus : Algoritma C4.5 Untuk Penjurusan Siswa SMA Negeri 3 Pati dengan kesimpulan klasifikasi Algoritma C4.5 dapat mengklasifikasi siswa untuk penjuruan kelas IPA dan IPS. Tingkat akurasi algoritma C4.5 sebesar 81,94\%. Dari permasalahan tersebut penulis mengangkat sebuah penelitian dengan judul "Analisa Faktor Dominan Mahasiswa Kesulitan Memahami Bahasa Pemrograman Menggunakan Metode C4.5". Diharapkan penelitian ini dapat menjadi keputusan dari hasil analisa yang dilakukan dan mencari solusi untuk mahasiswa mudah memahami bahasa pemrograman yang bertujuan sebagai dasar dalam menyelesaikan Tugas Akhir.

\section{METODOLOGI PENELITIAN}

\subsection{Analisis Data}

Dalam penelitian, data yang digunakan akan diolah dari hasil kuesioner yang diberikan kepada mahasiswa AMIK Tunas Bangsa angkatan 2016 dan 2017. Data yang digunakan terdiri dari :

1. Faktor dosen,

2. Faktor bahasa program,

3. Faktor fasilitas,

4. Faktor asisten lab komputer, dan

5. Faktor minat mahasiwa.

Setiap faktor terdiri dari pertanyaan yang diajukan ke mahasiswa yang diberikan. Kuesioner yang telah dilakukan selanjutnya mencari rata-rata dari faktor yang digunakan. Contoh Kuesioner dapat dilihat pada Lampiran. Data yang digunakan menggunakan jenis statistik deskriptif dengan kepada mahasiswa AMIK Tunas Bangsa. Kuesioner yang diberikan menggunakan linker 5 yang terdiri dari SB (Sangat Baik), B (Baik), CB (Cukup Baik), KB (Kurang Baik), dan SKB (Sangat Kurang Baik). Data diolah menggunakan RapidMiner dengan operator Performance yang berfungsi sebagai validasi dan reabilitas data untuk mencari keakuratan data. Data yang akurat, dilakukan pengolahan data untuk mencari hasil dari masalah penelitian dengan menggunakan RapidMiner dan diambil keputusan dari hasil. Berikut sampel data yang digunakan sebanyak 90 data angkatan 2016 dan 2017 pada Tabel 1 :

Tabel 1. Sampel Data

\begin{tabular}{|c|c|c|c|c|c|c|}
\hline No & Dosen & Bahasa & Fasilitas & Asisten Lab & Minat & Pemahaman \\
\hline 1 & Baik & Baik & Baik & Baik & Baik & Paham \\
\hline 2 & Baik & Baik & Baik & Sangat Baik & Cukup & Paham \\
\hline
\end{tabular}




\begin{tabular}{|c|c|c|c|c|c|c|}
\hline No & Dosen & Bahasa & Fasilitas & Asisten Lab & Minat & Pemahaman \\
\hline 3 & Baik & Baik & Baik & Baik & Baik & Paham \\
\hline 4 & Baik & Baik & $\begin{array}{c}\text { Sangat } \\
\text { Baik }\end{array}$ & Cukup & $\begin{array}{c}\text { Sangat } \\
\text { Baik }\end{array}$ & Paham \\
\hline 5 & Baik & Sangat Baik & Baik & Baik & Baik & Paham \\
\hline$\ldots$ & $\ldots$ & $\ldots$ & $\ldots$ & $\ldots$ & $\ldots$ & $\ldots$ \\
\hline 88 & Cukup & Baik & Cukup & Baik & Baik & Tidak Paham \\
\hline 89 & Baik & Baik & Baik & Baik & Baik & Paham \\
\hline 90 & Baik & Baik & Baik & Cukup & Cukup & Paham \\
\hline
\end{tabular}

\subsection{Data Mining}

Menurut [1] nama Data Mining sebenarnya mulai dikenal sejak tahun 1990, ketika pekerjaan pemanfaatan data menjadi sesuatu yang penting dalam berbagai bidang, mulai dari bidang akademik, bisnis, hingga medis. Munculnya Data Mining didasarkan pada jumlah data yang tersimpan dalam basis data semakin besar. Data Mining menurut [5] merupakan proses penggalian dan pertambangan pengetahuan dari sejumlah data yang besar, database atau repository database lainnya. Tujuan utama dari penambangan data ini untuk menemukan pengetahuan baru yang tersembunyi dari database tersebut.'

Data Mining bertujuan untuk memanfaatkan data dalam database dengan mengolah data tersebut sehingga menghasilkan informasi baru yang berguna untuk kepentingan perusahaan atau instansi. Data Mining mempunyai empat alur akar yang disajikan pada Gambar 1[1], yaitu :

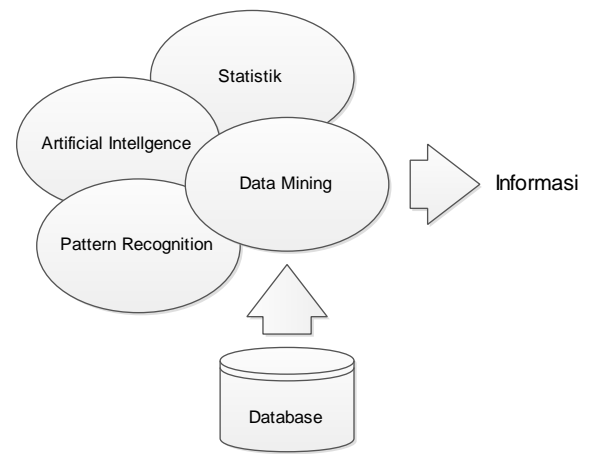

Gambar 1. Alur Akar Data Mining

Berdasarkan Gambar 1 memberikan penjelasan Alur Akar Data Mining sebagai berikut [1] :

1. Statistik

Dengan menggunakan statistik, data yang diolah dapat diringkas dalam yang dikenal sebagai Exploraty Data Analysis (EDA). EDA berguna untuk mengidentifikasi hubungan sistematis antar variable atau fitur ketika tidak ada cukup informasi alami.

2. Kecerdasan Buatan atau Artificial Intelligence (AI)

AI berkontribusi terhadap teknik pengolahan informasi berdasarkan pada model penalaran manusia. Salah satu cabang dari AI, yaitu pembelajaran mesin 
atau machine learning, merupakan disiplin ilmu yang paling penting yang dipresentasikan dalam pembangunan Data Mining.

3. Pengenalan Pola atau Pattern Recognition

Data yang diambil dari basis data untuk diolah dalam bentuk normal pertama sehingga set data dibentuk menjadi bentuk normal pertama.

4. Sistem Basis Data atau Database System

Akar bidang ilmu keempat dari Data Mining yang menyediakan informasi berupa data yang akan 'digali' menggunakan metode-metode yang disebutkan sebelumnya.

\subsection{Algoritma C4.5}

Algoritma C4.5 diperkenalkan oleh Quinlan (1996) sebagai versi perbaikan dari ID3. Dalam ID3, induksi Decision Tree hanya bisa dilakukan pada fitur bertipe kategorikal (nominal atau ordinal), sedangkan tipe numerik (interval atau rasio) tidak dapat digunakan [1]. Algoritma yang merupakan pengembangan dari ID3 ini dapat mengklasifikasikan data dengan metode pohon keputusan yang memiliki kelebihan dapat mengolah data numerik (kontinyu) dan diskret, dapat menangani nilai atribut yang hilang, menghasilkan aturan-aturan yang mudah di interprestasikan, dan tercepat diantara algoritma-algoritma yang menggunakan memori utama di komputer [6].

Kriteria yang paling banyak digunakan untuk memilih fitur sebagai pemecah dalam Algoritma C4.5 adalah Rasio Gain, yang diformulasikan oleh persamaan 1 berikut [2] :

$\operatorname{Gain}(S, A)=\operatorname{Entrropy}(S)-\sum_{i=1}^{n} \frac{\| S i \pi}{\|S\|} * \operatorname{Entropy}(S i)$

Keterangan :

S : Himpunan Kasus

A : Atribut

$\mathrm{N} \quad$ : Jumlah partisi atribut $\mathrm{A}$

|Si| : Jumlah kasus pada partisi ke i

|S| : Jumlah kasus dalam S

Sedangkan perhitungan nilai Entropy dapat dilihat pada persamaan 2 berikut [2] :

$\operatorname{Entropy}(A)=\sum_{i=1}^{n}-p i * \log _{2}$ pi

Keterangan :

S : Himpunan Kasus

A : Fitur

n : Jumlah partisi S

pi : Proporsi dari Si terhadap $S$

Kriteria yang paling banyak digunakan sebagai pemecah dalam Algoritma C4.5 adalah Gain Ratio (Rasio Gain), dengan persamaan 3 berikut [1]:

$\operatorname{RasioGain}(s, j)=\frac{\operatorname{Gain}(s, j)}{\operatorname{splithnfo}(s, j)}$

Keterangan :

Gain $(s, j) \quad$ : Nilai Information Gain

SplitInfo(s,j) : Nilai Split Info 
Dari persamaan (2.3) menyatakan nilai rasio gain pada fitur ke-j. SplitInfo(s,j) didapat dari persamaan 4 berikut [1] :

$\operatorname{SplitInfo}(s, j)=\sum_{i=1}^{k} p\left(v_{i} \mid s\right) \log _{2} p\left(v_{i} \mid s\right)$

Keterangan :

$\mathrm{s} \quad$ : Data yang digunakan untuk training / testing

j : : Atribut

$v_{\mathrm{i}} \quad$ : jumlah data untuk atribut ke-i

\subsection{RapidMiner}

Menurut[7] RapidMiner merupakan perangkat lunak yang bersifat terbuka (Open Source), sebuah salah satu solusi untuk melakukan analisis terhadap Data Mining. RapidMiner aplikasi yang berdiri sendiri untuk analisis data dan sebagai mesin Data Mining untuk integrasi kepada penelian atau suatu produk[8]. Hal ini digunakan untuk bisnis dan komersial, juga untuk penelitian, pendidikan, pelatihan, rapid prototyping, dan pengembangan aplikasi serta mendukung semua langkah dalam proses pembelajran mesin termasuk persiapan data, hasil visualisasi, validasi model dan optimasi.

Dalam penelitian ini penulis menggunakan operator Decision Tree pada software RapidMiner sebagai operator utama dalam pengerjaan penelitian ini. Berikut Gambar 2 menjelaskan bentuk Operator Decision Tree pada RapidMiner dan fungsinya :

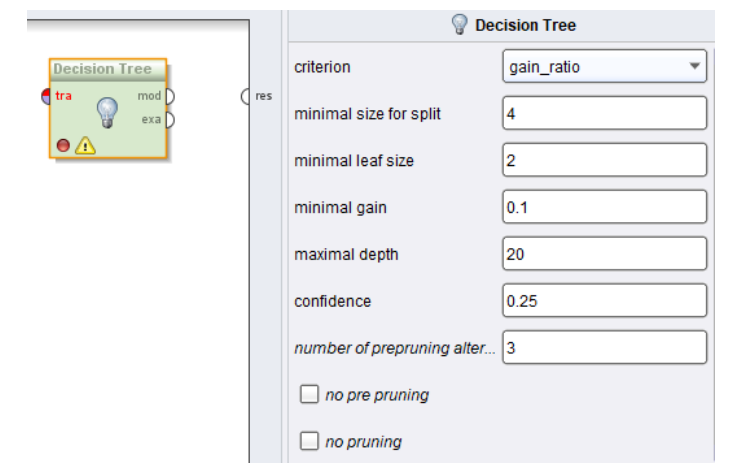

Gambar 2. Tampilan Operator Decision Tree pada RapidMiner

Berikut penjelasan parameter dari fungsi Decision Tree pada RapidMiner :

1. Criterion (Kriteria), memilih kriteria yang atributnya akan dipilih untuk pemisahan atau pembentukan Node. Terdiri dari Information Gain, Gain Ratio, Gini Index dan Accuracy.

2. Minimal Size for Split (Ukuran Miminal Untuk Split), merupakan ukuran minimal untuk parameter pemisahan dengan memisahkan simpul yang ukuran nilainya lebih besar.

3. Minimal Leaf Size (Ukuran Simpul Daun), pohon yang dihasilkan sedemikian rupa sehingga setiap subset simpul daun setidaknya memiliki jumlah contoh daun minimal.

4. Minimal Gain (Gain minimal), Gain dari sebuah node dihitung sebelum membelahnya. Node dibagi jika Gainnya lebih besar dari gain minimal. 
5. Maximal Depth (Kedalaman Maksimal), kedalaman pohon bervariasi tergantung pada ukuran dan sifat Contoh Set. Parameter ini digunakan untuk membatasi ukuran pohon keputusan.

6. Confidence (Kepercayaan), digunakan untuk menentukan tingkat kepercayaan yang digunakan untuk perhitungan kesalahan pemangkasan pesimistis.

7. Number of Prepruning Alternatives (Jumlah Alternatif Prapemesanan), dapat mencegah pemisahan pada node tertentu ketika membelah pada simpul tidak menambah kekuatan diskriminatif dai pohon keputusan.

\section{HASIL DAN PEMBAHASAN}

\subsection{Hasil}

Hasil penelitian yang dilakukan penulis dengan menggunakan Algoritma C4.5 dari data yang diberikan sebanyak 90 sampel data menghasilkan model aturan dan keputusan yang akan menjadi rekomendasi keputusan untuk pihak Akademik AMIK Tunas Bangsa dalam meminimalisir mahasiswa membeli program. Model Aturan yang dihasilkan dapat dilihat pada Gambar 3 berikut :

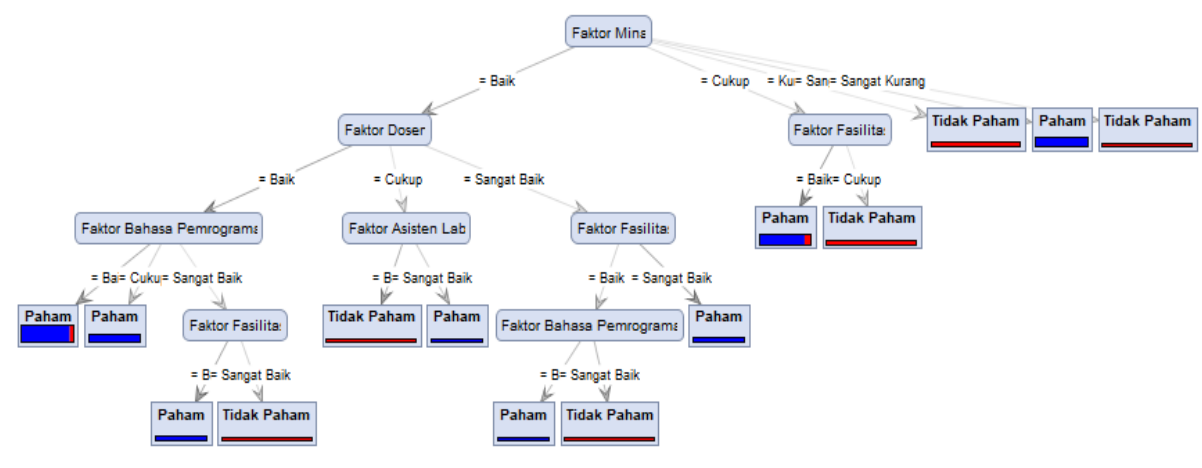

Gambar 3. Hasil Model Aturan di Software RapidMiner

Dari Gambar 2 dapat dihasilkan penyederhanaan aturan dari Decision Tree Algoritma C4.5 menggunakan Rule Induction pada RapidMiner. Dengan keterangan $\mathrm{P}=$ Paham dan $\mathrm{TP}=$ Tidak Paham penyederhanaan menggunakan Rule Induction dapat dilihat pada Tabel 2 berikut :

Tabel 2. Model Aturan Penyederhanaan Rule Induction

\begin{tabular}{|c|l|c|c|}
\hline Rule & \multicolumn{1}{|c|}{ Keterangan Rule } & P & TP \\
\hline \multirow{2}{*}{1} & Jika Faktor Minat = Sangat Baik & 13 & 0 \\
\cline { 2 - 4 } & Jika Faktor Fasilitas = Baik dan Faktor Minat = Cukup & 6 & 0 \\
\hline \multirow{2}{*}{2} & Jika Faktor Dosen = Baik maka = Tidak Paham & 0 & 4 \\
\cline { 2 - 4 } & Jika Faktor Dosen = Kurang = Tidak Paham & 0 & 2 \\
\hline
\end{tabular}

\subsection{Pembahasan}

Model yang dihasilkan oleh peneliti dan software RapidMiner dengan data sebanyak 90 terlihat bahwa mahasiswa yang Paham Bahasa Pemrograman sebanyak 83,33\% dan Tidak Paham Bahasa Pemrograman sebanyak 16,67\%. Hal ini menunjukkan untuk mahasiwa yang ingin lulus di Tahun 2019 dan 2020 secara dominan mampu menyelesaikan program dari Tugas Akhir. Secara keseluruhan 
mahasiswa AMIK Tunas Bangsa yang Tidak Paham Bahasa Pemrograman, dapat dilihat dari model aturan yang dihasilkan untuk memberi keputusan oleh pihak Pendidik untuk mengatasi ketidakpahaman mahasiswa terhadap Bahasa Pemrograman sebagai hasil akhir dari Tugas Akhir yang dilakukan mahasiswa. Hasil yang didapatkan terlihat mahasiswa yang Tidak Paham tidak lebih dari 50\%, pengujian ketika Sidang Tugas Akhir masih banyak mahasiswa yang tidak paham ketika penguji memberikan pertanyaan kepada mahasiswa tentang program yang dibuat mahasiswa.

Dari data yang dihasilkan terlihat bahwa Faktor Dosen menjadi Faktor yang menghasilkan Tidak Paham dengan atribut Baik sebanyak 4 dan artibut cukup sebanyak 2. Pihak pendidik khususnya dosen perlu memberikan pendidikan yang baik dan benar dalam hal memudahkan mahasiswa dalam mempelajari Bahasa Pemrograman. Faktor pertama dari hasil penelitian adalah Faktor Minat, artinya minat mahasiswa sangat mempengaruhi pemahaman mahasiswa, jika minat mahasiswa cenderung cukup atau kurang dapat berisiko tidak paham terhadap Bahasa Pemrograman. Faktor Fasilitas merupakan faktor ketiga setelah Faktor Dosen, artinya fasilitas yang diberikan oleh AMIK dan Tunas Bangsa cukup berpengaruh terhadap proses belajar bahasa pemrograman. Bahasa Pemrograman memerlukan perangkat yang baik agar tidak ada kendala ketika pengetikan pemrograman. Faktor Bahasa Pemrograman dan Faktor Asisten Lab merupakan faktor ke- 4 dan ke- 5 setelah Faktor Dosen. Artinya Bahasa Pemrograman yang diajarkan dosen sebaiknya dinamis mengikuti perkembangan dunia industri dan mudah dipahami mahasiswa. Asisten Lab diharapkan juga membimbing mahasiswa ketika praktikum di Laboratorium untuk memudahkan mahasiswa terhadap Bahasa Pemrograman.

\section{KESIMPULAN}

Algoritma C4.5 dapat digunakan sebagai salah satu metode untuk klasifikasi dalam menentukan mahasiwa Paham atau Tidak Paham terhadap Bahasa Pemrograman yang diajarkan di AMIK Tunas Bangsa. Terdapat 90 data yang diolah di RapidMiner menunjukkan hasil akurasi sebesar 84,44\% dengan 75 responden menyatakan Paham dan 15 responden menyatakan Tidak Paham. Penelitian ini menunjukkan hasil yang diperoleh oleh RapidMiner menunjukkan atribut Faktor Minat sebagai node pertama, Faktor Dosen sebagai node kedua, Faktor Fasilitas sebagai node ketiga, Faktor Bahasa Pemrograman sebagai node keempat dan node Asisten Lab sebagai node kelima dalam pengolahan data menggunakan Algoritma C4.5. Dapat disimpulkan pihak akademik khususnya dosen memberikan pendidikan yang baik dan memberikan motivasi bahwa bahasa pemrograman dinamis mengikuti perkembangan zaman terutama dunia industri dengan dibantu fasilitas yang baik dan nyaman, jenis bahasa pemrograman yang mudah dipahami mahasiswa, dan asisten lab yang memimbing mahasiswa yang kesulitan selama proses praktikum berlangsung.

\section{DAFTAR PUSTAKA}

[1] Prasetyo, Data Mining Mengolah Data Menjadi Informasi Menggunakan Matlab. ANDI, 2014.

[2] M. A. Sembiring, M. F. L. Sibuea, and A. Sapta, "Analisa Kinerja Algoritma C4.5 Dalam 
Memprediksi Hasil Belajar," JSSR, no. February, pp. 73-79, 2018.

[3] Y. sulistio Nugroho, "Penerapan Algoritma C4.5 untuk Klasifikasi Predikat Kelulusan Mahasiswa Fakultas Komunikasi dan Informatika Universitas Muhammadiyah Surakarta," SNAST, pp. 1-6, 2014.

[4] E. B. Rahayu, “Algoritma C4 . 5 Untuk Penjurusan Siswa SMA NEGERI 3 PATI,” Progr. Stud. Tek. Inform. Fak. Ilmu Komput., pp. 3-6, 2014.

[5] E. Elisa, "Analisa dan Penerapan Algoritma C4.5 Dalam Data Mining Untuk Mengidentifikasi Faktor-Faktor Penyebab Kecelakaan Kerja Kontruksi PT.Arupadhatu Adisesanti,” J. Online Inform., vol. 2, no. 1, p. 36, 2017.

[6] R. K. Amin, Indwiarti, and Y. Sibaroni, "Implementasi Klasifikasi Decision Tree Dengan Algoritma C4.5 Dalam Pengambilan Keputusan Permohonan Kredit Oleh Debitur,” vol. 2, no. 1, pp. 1768-1778, 2015.

[7] Q. Tanjung, "Sistem Penunjang Keputusan Kelayakan Kredit Motor Menggunakan Metode Naive Bayes Pada NSC Finance Cikampek," 2017.

[8] S. Lambertus, “Optimasi Kinerja Firewall Menggunakan Teknik Data Mining,” 2018. 